ISSN 1999-4923

www.mdpi.com/journal/pharmaceutics

Review

\title{
Tissue Engineered Human Skin Equivalents
}

\section{Zheng Zhang ${ }^{1}$ and Bozena B. Michniak-Kohn ${ }^{2, *}$}

1 New Jersey Center for Biomaterials, Rutgers - The State University of New Jersey, Piscataway, NJ 08854, USA

2 Ernest Mario School of Pharmacy, Department of Pharmaceutics, Rutgers - The State University of New Jersey, Piscataway, NJ 08854, USA

* Author to whom correspondence should be addressed; E-Mail: michniak@biology.rutgers.edu; Tel.:+1-732 445 3589; Fax: +1-732 4455006.

Received: 16 November 2011; in revised form: 15 December 2011 / Accepted: 26 December 2011 / Published: 6 January 2012

\begin{abstract}
Human skin not only serves as an important barrier against the penetration of exogenous substances into the body, but also provides a potential avenue for the transport of functional active drugs/reagents/ingredients into the skin (topical delivery) and/or the body (transdermal delivery). In the past three decades, research and development in human skin equivalents have advanced in parallel with those in tissue engineering and regenerative medicine. The human skin equivalents are used commercially as clinical skin substitutes and as models for permeation and toxicity screening. Several academic laboratories have developed their own human skin equivalent models and applied these models for studying skin permeation, corrosivity and irritation, compound toxicity, biochemistry, metabolism and cellular pharmacology. Various aspects of the state of the art of human skin equivalents are reviewed and discussed.
\end{abstract}

Keywords: human skin equivalents; tissue engineering; regenerative medicine; skin grafts; skin models

\section{Human Skin and Skin Barrier}

Human skin, as the largest organ in the body, is an anatomical barrier between the internal and external environment; it protects the body from toxic substances, pathogens, and organisms. Human 
skin is also involved in a number of physiological functions such as fluid homeostasis, thermoregulation, immune surveillance, self-healing, as well as sensory detection [1].

Human skin consists of the epidermis and dermis, the epidermis being the outer layer of the skin. The major cells of the epidermis are keratinocytes (90-95\%), which proliferate in the stratum basale (the deepest layer of epidermis). As the basal keratinocytes proliferate, the "daughter" cells migrate superficially and differentiate, forming the stratum spinosum (a layer of spinous cells where keratinization begins), stratum granulosum (a granular layer where further differentiated keratinocytes become granular cells that contain keratohyalin granules), stratum lucidum (a thin and clear/translucent layer of dead cells; this layer is mostly only seen in palms and soles), and stratum corneum (a cornified layer consisting of corneocytes, dead cells lacking nuclei and organelles), respectively. The stratum corneum has been proposed to possess a "bricks and mortar" structure, in which the corneocytes represent the "bricks" and the intercellular lamellar lipid bilayers represent the "mortar"; this layer provides the most significant contribution to the permeation barrier properties of human skin [2].

Other cells that play a functional role in the epidermis include Langerhans cells (dendritic cells that are present in the stratum spinosum and contribute to the immunological responses of the skin), melanocytes (present in the stratum basale and produce melanin, which contributes to skin pigmentation and protects the skin from harmful ultraviolet radiation), and Merkel-Ranvier cells (the oval receptor cells present in the stratum basale that contribute to sensory reception).

The epidermis layer is bound tightly to the underlying dermis layer via basement membrane at the Dermal-epidermal junction (DEJ). The basement membrane can be divided into lamina lucida (the layer closer to the epidermis; this layer is made up of laminin, integrins, entactins, and dystroglycans) and lamina densa (a sheet-like structure composed mainly of type IV collagen).

The dermis lies between the epidermis and the subcutaneous tissues, and is composed of the papillary dermis and the reticular dermis. The papillary dermis intertwines with the epidermis, forming rete pegs and rete ridges along the DEJ [3]; as a result, the surface contact area between the epidermis and the dermis increases. The reticular dermis is the site of the dense collagen and elastic fiber matrix, and it is the main source of the strength, flexibility and elasticity of the skin. The three major cell types of the dermis are fibroblasts, macrophages, and adipocytes, among those fibroblasts produce collagens, elastic fibers, glycosaminoglycans, and glycoproteins.

Associated with the epidermis and dermis are skin appendages possessing different functions such as sweat glands that regulate body temperature by secreting sweat onto the surface of the skin; sebaceous glands that secrete sebum to moisturize the skin and hair; hair follicles that play an important role in wound healing, as they are a source of keratinocyte proliferation during reepithelialization [4]; arrector pilli muscles that pull hairs straight; and nails that protect distal phalanx and the fingertip.

Human skin not only serves as an important barrier against the penetration of exogenous substances into the body, but also provides a potential avenue for the transport of functional active drugs/reagents/ ingredients into the skin (topical delivery) and/or the body (transdermal delivery). It is proposed that the compounds penetrate the skin using the following pathways [5]: 
(a) through stratum corneum via intercellular route and/or intracellular route, and then through the viable epidermis and dermis via partitioning/diffusion;

(b) through the appendageal pathway.

Recently, M.S. Roberts and his group proposed a solute structure-skin transport model for aqueous solutions in which permeation rates depend on both partitioning and diffusivity: Partitioning is related to octanol-water partition coefficient, and diffusivity to solute size and hydrogen bonding [6].

\section{Tissue Engineered Human Skin Equivalents}

\subsection{Tissue Engineering and Regenerative Medicine}

The most significant and costly problem in healthcare today is the loss or failure of a tissue or organ. In recent years, tissue/organ transplantations of bone, tendon, cornea, heart valve, vein, skin, kidney, heart, lung, liver, pancreas, and intestine, etc., have been used clinically to save lives [7]. Tissues and organs that are transplanted within the same person's body are called autografts; transplants that are performed between two individuals are called allografts.

In very limited cases, the patients have suitable autografts for transplantation. For allografts, the demand for tissues and organs seriously exceeds the supply, creating a substantial waiting list; moreover, the immune system tends to reject the foreign tissue or organ. Most organ recipients take immunosuppressive drugs for the rest of their lives; further, immunological imbalances caused by transplantation often lead, on the long term, in tumor growth [8].

Therefore, there is a significant need for tissue engineering and regenerative medicine approaches aiming at generation of implantable or in situ forming tissues and organs. In the tissue engineering approach, cells are seeded in a biodegradable matrix or scaffold. The matrix/scaffold provides adequate three-dimensional structure of the target tissue. While the cells proliferate and differentiate, producing extracellular matrices (ECM), the matrix/scaffold degrades; these processes can eventually result in the formation of functional tissues [8]. Regenerative medicine approaches share the same principles as tissue engineering, but emphasize more the utilization of patients' only cells e.g., stem cells.

For commercializable clinical applications, reliable cell sourcing and isolation methods play a critical role in providing a sufficient amount of cells for tissue engineering and regenerative medicine approaches. Rheinwald and Green first reported the isolation and serial cultivation of human epidermal keratinocytes from a small biopsy of skin, and the formation of keratinizing colonies from single cells [9]; then, they found that cells growing in the presence of epidermal growth factor (EGF) retained a higher colony forming efficiency [10]. Green et al. further reported the method of transferring the intact epithelium sheets using protease Dispase. An estimation of 6000-fold increase in size of total harvest epithelium as compared to that of the initial skin biopsy was made accordingly [11]. Rheinwald and Green's work provided the method to obtain sufficient keratinocytes for (large-scale) bioengineering of human skin substitutes [12].

For keratinocytes and more importantly for stem cells, the sourced cells need to proliferate and differentiate in appropriate manners; to achieve this result biological growth factors have been utilized. Experiments have shown that platelet-derived growth factors (PDGF) accelerated the normal healing process and up-regulated the genes necessary for wound healing [13]. Another approach to stimulate 
cell proliferation and differentiation is through in vitro cell culture bioreactors that simulate biochemical and mechanical signals and regulate tissue development [14]. Bioreactors have three major components: metabolically active cells that express their differentiated phenotype and produce ECM; polymeric scaffolds providing three dimensional structural supports for cell attachment and tissue growth, being matrices for nutrients/oxygen/waste transport and media for biological and mechanical stimuli; and an environment mimicking in vivo conditions where cell-polymer complex can develop into tissues [15].

The selection of the scaffolding materials also plays an essential role [16]. Biologically derived, natural macromolecules are exemplified by type I collagen, glycosaminoglycan, and chitosan; the most applied synthetic polymers are aliphatic polyesters based on lactide, glycolide and $\varepsilon$-caprolactone; the concept of creating polymers from naturally occurring metabolites has been intensively explored by Kohn et al., a framework of utilizing tyrosine-derived polymers for tissue engineering applications has been created $[17,18]$.

The use of hydrogels as scaffolding materials is another advancement in tissue engineering. Hydrogels have been made using various natural macromolecules including: agarose, alginate, chitosan, collagen, hyaluronan, fibrin, and among others [19]. These hydrogels have high water content and possess structural resemblance to ECM of many tissues. They can be delivered, together with the cells, into the location of tissue defects in a minimally invasive manner [20]; also, nano- and (micro)particles loaded with hydrophilic peptides, proteins, and growth factors can be incorporated into hydrogels, forming novel drug delivery systems [21].

In the field of regenerative medicine, Atala et al. developed whole organ decellularization technique for the fabrication of bioscaffolds that can be applied for organ bioengineering. Decellularization approach selectively removed only the cellular component of a tissue, while the structure of ECM and vascular network remained [22]. Then, the cultivated cells originated from the patient's own body were seeded into the bioscaffolds; subsequent culture of the cells-bioscaffolds complexes would result in artificial organs with much lower risk of rejection as compared to a regular organ transplant [23].

\subsection{Need and Criteria for Human Skin Equivalents}

Human skin equivalents (HSEs) are bioengineered substitutes composed of primary human skin cells (keratinocytes, fibroblasts and/or stem cells) and components of ECM (mainly collagen). In the last three decades, tremendous efforts have been devoted to the research and development of HSEs, resulting in a number of clinical products and skin models for pharmaceutical and cosmetic companies. In general, HSEs are applied in two major categories: (a) as clinical skin replacements and grafts; and (b) as models for drug permeability tests and toxicity screening. Table 1 summarizes the commercially available HSEs products.

Skin injuries (from burn, accident, acute trauma or chronic wounds, and diseases, etc.) can compromise skin barrier and lead to permanent disability or death of the injured person depending on the severity of the wound. Wound dressings that cover the site of the wound allow the reepithelialization, remodeling of granulation tissue, and formation of scar tissue [4]. However, full-thickness skin is not generated in this way. Clinical skin replacements and grafts are in high demand for the treatment of skin injuries: they represent approximately $50 \%$ of tissue engineering and regenerative medicine market revenues. In 2009, the potential United States market for 
tissue-engineered skin replacements and substitutes totaled approximately $\$ 18.9$ billion, based on a target patient population of approximately 5.0 million. By the year 2019, the total potential target population for the use of tissue-engineered skin replacements and substitutes is expected to increase to 6.4 million, resulting in a potential US market of approximately \$24.3 billion [24].

Table 1. Summary of commercially available human skin equivalents.

\begin{tabular}{|c|c|c|c|}
\hline Brand & Company & FDA Approval & Product Description \\
\hline \multicolumn{4}{|c|}{ 1. Clinical skin replacements and grafts } \\
\hline $\begin{array}{l}\text { Integra }{ }^{\circledR} \text { DRT (Dermal } \\
\text { Regeneration Template) }\end{array}$ & Integra Lifesciences & 1996 & $\begin{array}{l}\text { Thin silicone film covering a porous matrix of cow collagen } \\
\text { and glycosaminoglycan }\end{array}$ \\
\hline Apligraf $^{\circledR}$ & Organogenisis & 1998 & $\begin{array}{l}\text { Fibroblasts and collagen combined in dermal matrix onto } \\
\text { which keratinocytes are seeded to form an epidermal layer }\end{array}$ \\
\hline Epicel $^{\circledR}$ & Genzyme & 2007 & $\begin{array}{l}\text { Autologous keratinocytes grown ex vivo in the presence of } \\
\text { proliferation-arrested mouse fibroblasts }\end{array}$ \\
\hline Transcyte $^{\circledR} /$ Dermagraft ${ }^{\circledR}$ & $\begin{array}{l}\text { Advanced Tissue } \\
\text { Sciences/Advanced }\end{array}$ & $1997 / 2001$ & $\begin{array}{l}\text { Cryopreserved dermal substitute: human fibroblast seeded } \\
\text { onto polymer mesh and cultured ex vivo }\end{array}$ \\
\hline Orcel $^{\circledR}$ & $\begin{array}{l}\text { Biohealing } \\
\text { FortiCell Bioscience }\end{array}$ & $2001 / 2008$ & $\begin{array}{l}\text { Human epidermal keratinocytes and dermal fibroblasts are } \\
\text { cultured in separate layers into a Type I bovine collagen } \\
\text { sponge }\end{array}$ \\
\hline Alloderm ${ }^{\circledR} /$ Strattice $^{\circledR}$ & LifeCell Co. & None & Acellular cadaver skin matrix \\
\hline StrataGraft $^{\circledR}$ & StrataTech & None & $\begin{array}{l}\text { Full thickness skin substitute where a near-diploid human } \\
\text { keratinocytes cell line, NIKS, was utilized. }\end{array}$ \\
\hline \multicolumn{4}{|c|}{ 2. In Vitro Permeation and Toxicity Screening Models } \\
\hline $\begin{array}{l}\text { SkinEthic Rhe } \\
\text { (Reconstructed Human } \\
\text { Epidermis) }\end{array}$ & SkinEthic & & $\begin{array}{l}\text { Human keratinocytes cultured on an inert polycarbonate } \\
\text { filter at the air-liquid interface in chemically defined } \\
\text { medium }\end{array}$ \\
\hline Episkin & SkinEthic & & $\begin{array}{l}\text { Human keratinocytes cultured on a collagen base which } \\
\text { permit terminal differentiation and reconstruction of the } \\
\text { epidermis with a functional stratum corneum }\end{array}$ \\
\hline Epiderm & MatTek & & $\begin{array}{l}\text { Neonatal human-derived epidermal keratinocytes (NHEK) } \\
\text { cultured to form a multi-layered, highly differentiated model } \\
\text { of the human epidermis }\end{array}$ \\
\hline EpidermFT & MatTek & & $\begin{array}{l}\text { Neonatal human-derived dermal fibroblasts (NHFB) and } \\
\text { NHEK co-cultured to form a multi-layered, highly } \\
\text { differentiated model of the human dermis and epidermis }\end{array}$ \\
\hline StrataTest & StrataTech & & $\begin{array}{l}\text { Full thickness skin model where a near-diploid human } \\
\text { keratinocytes cell line, NIKS, was utilized. }\end{array}$ \\
\hline $\begin{array}{l}\text { Epidermal Skin Test } 1000 \\
\text { (EST1000) }\end{array}$ & $\begin{array}{l}\text { CellSystems } \\
\text { Biotechnologie } \mathrm{GmbH}\end{array}$ & & $\begin{array}{l}\text { Reconstructed epidermal model made from primary human } \\
\text { keratinocytes; it comprises a fully differentiated epidermis } \\
\text { with viable and cornifiedcell layers }\end{array}$ \\
\hline $\begin{array}{l}\text { Advanced Skin Test } 2000 \\
\text { (AST2000) }\end{array}$ & $\begin{array}{l}\text { CellSystems } \\
\text { Biotechnologie GmbH }\end{array}$ & & $\begin{array}{l}\text { It comprises a dermal equivalent with embedded fibroblasts } \\
\text { as a basis and epidermal layer of keratinocytes on top; it is a } \\
\text { full thickness model. }\end{array}$ \\
\hline
\end{tabular}


The other field of application for HSEs is as models for drug/ingredient permeability testing and toxicity screening. Animal testing of cosmetic ingredients is strictly limited in the European Union; even if no alternative tests are available, the majority of the animal tests are banned [25]. Human cadaver skin and excised animal skin have been traditionally used as topical and transdermal permeation models [26]. Although human cadaver skin replicates in vivo permeation performance to some extent, there is a high sample to sample variation. Animal skin, though easily procured, is morphologically different to human skin. Therefore, there is a commercial need for better HSEs that serve as a suitable model for various skin tests.

For pharmaceutical companies, HSEs can provide specific skin models for diseases such as vitiligo, melanoma, squamous cell carcinoma, psoriasis, and blistering skin disorders as well as models for healthy skin ([27-29], for additional information, see Section 2.4 below); this is a unique advantage over the cadaver skin and animal skin specimens.

HSEs can be designed as epidermis only, dermis only, or full thickness (both dermis and epidermis) depending on the application [30]. The ideal HSEs should have differentiated epidermis morphology, appropriate protein expression, similar lipid contents and lipid multi-lamellar structures as those of human skin [31]; the HSEs should be easy to handle and transport, and should be easy to package and ship. When used as a permeation model for drugs/ingredients, the HSEs should produce consistent data that predict the permeation behavior of the tested compounds through human skin.

\subsection{Commercially Available Human Skin Equivalents for in Vivo Applications: Clinical Skin Replacements and Skin Grafts}

Tissue engineered HSEs are the first commercially available and clinically applied organ substitutes [4]. The success was achieved due to major advancements in keratinocyte cell biology, ECM biology, production of collagen scaffolds and polymeric scaffolds, and stem cell biology [32].

When skin is wounded, a cascade of biological responses occurs after hemostasis: it begins with immune cells migrating to the site of injury, followed by fibroblasts generating a new tissue matrix; concurrently, reepithelialization and revascularization occur [33]. Without a graft, a full-thickness skin damage of diameter larger than $4 \mathrm{~cm}$ is difficult to heal [34].

Skin autografts are harvested from uninjured areas and then applied to the excised or debrided areas of the wounded skin of the same individual. Upon application of the skin graft, the capillary network of the wound will merge with the skin graft. However, several problems arise from skin autografts: significant scarring and pigmentation, often the dermis is not replaced, harvesting skin causes a new wound at the donor site, and extensive skin damage cannot be treated using skin autografts [35]. Allogeneic skin grafts harvested from cadavers can also be used; however they face immunogenic rejection and must be replaced [36]. Therefore, bioengineered HSEs could be used to provide a more permanent solution.

Currently, several HSEs are commercially available for clinical applications. Examples include

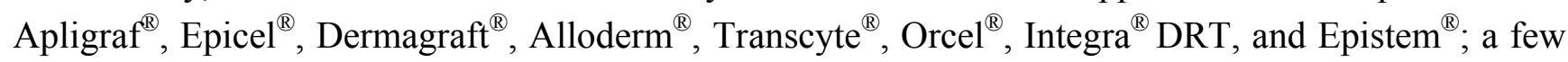
others are currently under clinical trial, one example is StrataGraft ${ }^{\circledR}$ developed by StrataTech Corp. These HSEs can be divided into three major categories: epidermal, dermal, and full-thickness models. 


\subsubsection{Epidermal Models}

Epidermal skin replacements require a $2-5 \mathrm{~cm}^{2}$ skin biopsy from which the epidermis is separated and the keratinocytes are isolated and cultured on top of fibroblasts [36]. Several companies offer epidermal HSEs including Genzyme's Epicel ${ }^{\circledR}$ (Cambridge, MA, USA). Epicel ${ }^{\circledR}$ is based on the use of a cultured epithelium prepared from autologous epidermal cells on grafts of burn wounds [37].

\subsubsection{Dermal Models}

Dermal skin replacements add greater mechanical stability and prevent the wound from contracting.

Transcyte $^{\circledR}$, a product made by Advanced Tissue Sciences, Inc. (La Jolla, CA, USA), utilizes seeded neonatal human dermal fibroblasts in a polymeric scaffold that is then cryopreserved, making it a non-living wound covering. Transcyte ${ }^{\circledR}$ has been successfully used as a temporary wound covering after the burn wound has been excised [38]. A derivative of this product, Dermagraft ${ }^{\circledR}$ by Advanced Biohealing, utilizes a biodegradable polygalactin mesh and has shown limited success in diabetic foot ulcer treatment [39].

LifeCell (Branchburg, NJ, USA) developed Alloderm ${ }^{\circledR}$ and Strattice ${ }^{\circledR}$, intact acellular matrices produced from cadaver skin by removing epidermis and the antigenic cellular elements in the dermis. Often, autologous keratinocytes were seeded and cultured on Alloderm ${ }^{\circledR}$ to form epithelium, and the epithelium-Alloderm ${ }^{\circledR}$ structure can be applied for wound and burn closure [40].

A composite skin graft composed of an outer layer of thin silicone film and an inner layer constructed of a complex matrix of crosslinked fibers is marketed under the product name Integra ${ }^{\circledR}$ Dermal Regeneration Template (Intergra ${ }^{\circledR}$ DRT, Integra Life Sciences Corp.; Plainsboro, NJ, USA). Once dermal layer is regenerated, the silicone film on the dermal layer can be removed and replaced with an epidermal autograft. Integra ${ }^{\circledR}$ DRT has been successfully shown to treat burns [41].

\subsubsection{Full-Thickness Models}

Full-thickness models of HSEs are composed of both epidermal and dermal layers; keratinocytes and fibroblasts, either autologous or allogeneic, are utilized to prepare the bilayer structures [42]. Histological data from Maruguchi et al.'s study indicated that keratinocytes cultured for one week on fibroblasts that had been seeded and cultured in a sponge resulted in optimum proliferation and differentiation of keratinocytes and most closely resembled the histology of the epidermis in vivo. In addition, the fibroblasts in the dermal layer provided an ample support matrix for the keratinocytes [43].

An early example of full-thickness HSEs was bioengineered from a fibroblasts laced collagen lattice covered with epidermal cells [12]. Based on this pioneer work, Organogenesis (Canton, MA, USA) became one of the first tissue-engineering companies and developed the bilayered skin model Apligraf $^{\circledR}$. Apligraf ${ }^{\circledR}$ is made of living allogeneic human skin fibroblasts that are obtained from human foreskins and soluble type I bovine collagen in the form of a gel seeded with keratinocytes. Apligraf ${ }^{\circledR}$ has been used in surgical wound healing [44] and venous ulcers [45], but not with major burns [46].

PermaDerm $^{\circledR}$ (Regenicin, Inc) is a promising new product that can act as a permanent cover of large burns and injuries. It uses keratinocytes and fibroblasts seeded into a collagen sponge [47]. 


\subsection{Commercially Available Human Skin Equivalents for in Vitro Applications: Models for Drug} Permeability Tests and Toxicity Screening

HSEs are used as models for in vitro testing [48], and can demonstrate fundamental biological processes of the skin such as the examination of different stimuli that lead to the formation of the epidermis [49], stem cell maintenance [50], wound healing processes [51], the effect of corrosiveness of various chemicals on the skin [52], phototoxicity of substances [53], and toxicity of various chemicals without the need for animal testing.

HSEs can be utilized to test the permeability of skin to various topically applied cosmetics/personal care agents and drugs. It is important for cosmetic and pharmaceutical companies to have a reliable in vitro screening system to test the amount of drugs/active ingredients that permeate into the epidermis [54], dermis, and across the membrane [55]. In recent years, companies such as L'Oreal and SkinEthic have invested heavily in the development of skin models for pharmaceutical, cosmetic and chemical compound testing [27].

The skin permeability barrier that resides in the stratum corneum, is composed of a combination of skin lipids, including: ceramides, cholesterol, cholesterol esters and free fatty acids, which are packed into the intercorneocyte space to form multi-lamellar sheets [56]. The presence of the intercorneocyte space has been confirmed through experimentation to be the main route of permeation for most compounds [6,57]. Therefore, in order to create a viable permeation barrier the epidermal differentiation process and the subsequent lipid accumulation and organization need be comparable to that of human skin [28].

HSEs for in vitro permeation and toxicity applications can be divided into two major categories: namely epidermis-only models and full thickness models. In US, MatTek Corp. developed a serial of HSE models e.g., Epiderm ${ }^{\circledR}$ (human keratinocytes-derived multi-layered model of human epidermis), EpidermFT (human keratinocytes and dermal fibroblasts derived multi-layered model of human epidermis and dermis), MelanoDerm ${ }^{\mathrm{TM}}$ skin model (based on co-culture of human keratinocytes and melanocytes), and Melanoma skin model (melanoma cells combined with EpidermFT). Also, StrataTech Corp. (Madison, WI, US) developed a full thickness StrataTest ${ }^{\circledR}$ skin model where a near-diploid human keratinocytes cell line, NIKS, was utilized.

In Europe, SkinEthic/L'Oreal (France) developed epidermis models SkinEthic ${ }^{\circledR}$ Rhe (Reconstructed human epidermis) and Episkin ${ }^{\circledR}$, and full thickness model RealSkin ${ }^{\circledR}$. Epidermal-skin-test 1000 (EST1000, an epidermis model) and Advanced-skin-test 2000 (AST2000, a full thickness model) were developed by CellSystems Biotechnologie GmbH (Germany).

For these HSEs, the differentiation of epidermis is a key factor determining their barrier properties. Figure 1A,B show the H\&E stained images of an EpiSkin ${ }^{\circledR}$ and a RealSkin ${ }^{\circledR}$ specimen, respectively. In both HSE models, the stratum basale layer (SB), granular cells (g), and stratum corneum (SC) are evident. For RealSkin ${ }^{\circledR}$ specimen, a few fibroblasts (f) are shown, though the typical rete pegs and rete ridges structures along the dermal-epidermal junction in human skin are absent. These images are representative for HSEs of epidermis model and full thickness model, respectively. 
Figure 1. Hematoxylin and Eosin (H\&E) stained EpiSkin ${ }^{\circledR}(\mathbf{A}, 40 \times)$ and RealSkin ${ }^{\circledR}$ (B, 40×) specimens. The HSE samples were received from SkinEthic/L'Oreal (France) and fixed with 4\% paraformaldehyde; after dehydration, the specimens were embedded in paraffin, and sectioned into $8 \mu \mathrm{m}$ thickness. SB: stratum basale; G: granular cells; SC: stratum corneum; F: fibroblasts (bar $=100 \mu \mathrm{m})$.
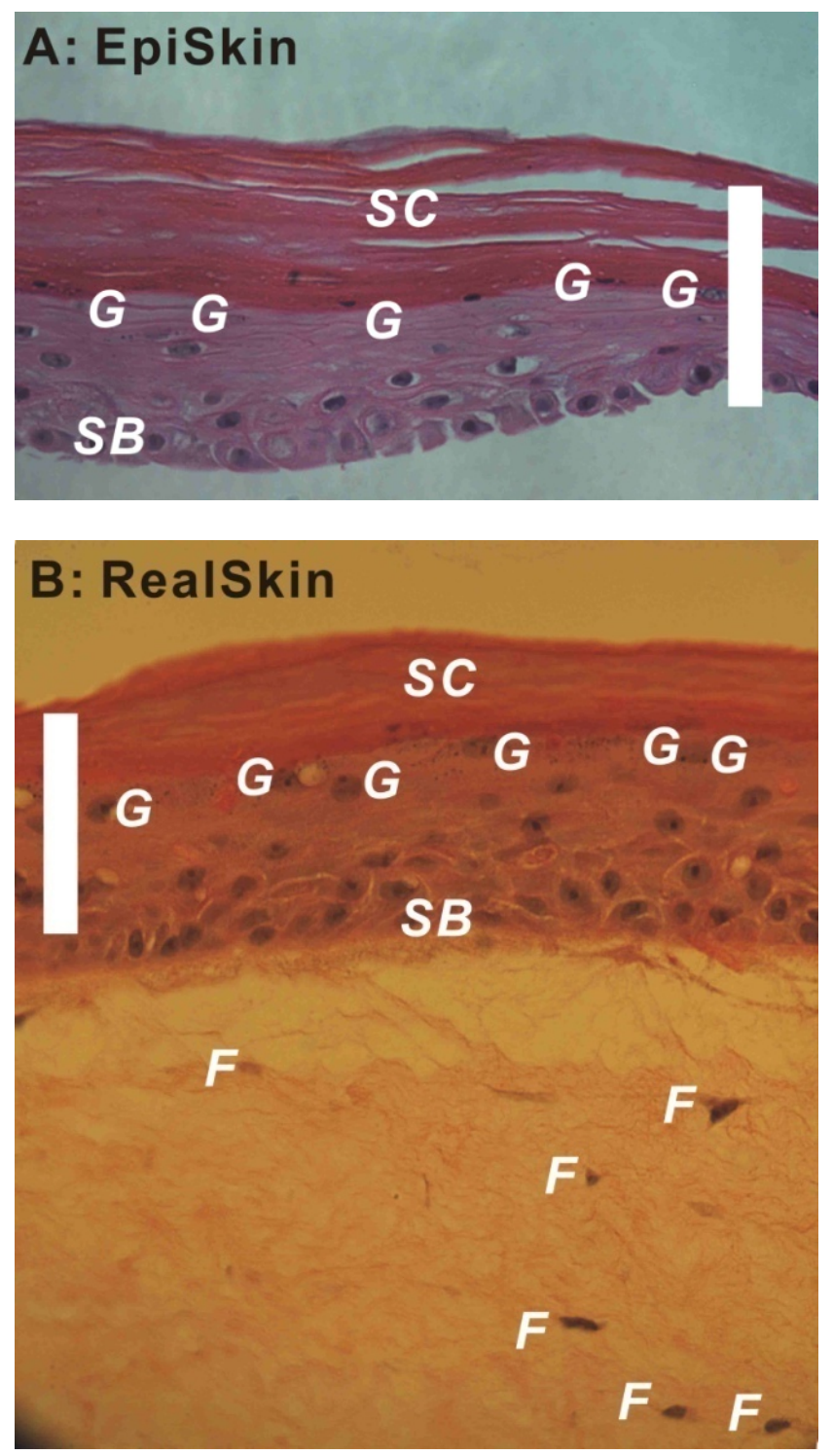

The usage of HSEs as alternatives for animal testing must be validated: the batch-to-batch reproducibility of compound permeability must be observed over a long period of time, and multi-laboratory studies need be carried out independently. A number of alternative safety testing methods, where HSEs can be applied as models in the skin corrosivity test and skin irritation test, have been validated by US and international regulatory authorities. These validated alternative methods are listed in Table 2. 
Table 2. Validated alternative methods where human skin equivalents (HSEs) can be applied as models in the skin corrosivity test and skin irritation test.

\begin{tabular}{|c|c|c|c|}
\hline $\begin{array}{l}\text { Brand of } \\
\text { HSE Models }\end{array}$ & Company & $\begin{array}{l}\text { US Regulatory } \\
\text { Acceptance/Endorsement by } \\
\text { NICEATM-ICCVAM [58] }\end{array}$ & $\begin{array}{l}\text { EU Regulatory Acceptance/Endorsement by } \\
\text { ECVAM [59] }\end{array}$ \\
\hline \multicolumn{4}{|c|}{ Skin Corrosivity Test } \\
\hline EpiSkin $^{\mathrm{TM}}$ & SkinEthic & $\begin{array}{l}\text { OECD Test Guideline } 431 \\
\text { accepted in } 2004\end{array}$ & $\begin{array}{l}\text { Commission Regulation (EC) No 440/2008; } \\
\text { OECD Test Guideline } 431 \text { (April 1998) }\end{array}$ \\
\hline Epiderm $^{\mathrm{TM}}$ & MatTek & $\begin{array}{l}\text { OECD Test Guideline } 431 \\
\text { accepted in } 2004\end{array}$ & $\begin{array}{l}\text { Commission Regulation (EC) No 440/2008; } \\
\text { OECD Test Guideline } 431 \text { (March 2000) }\end{array}$ \\
\hline $\begin{array}{l}\text { SkinEthic } \\
\text { Rhe }\end{array}$ & SkinEthic & $\begin{array}{l}\text { OECD Test Guideline } 431 \\
\text { (meets performance standards } \\
2006 \text { ) }\end{array}$ & $\begin{array}{l}\text { Commission Regulation (EC) No 440/2008; } \\
\text { OECD Test Guideline } 431 \text { (November 2006) }\end{array}$ \\
\hline EST1000 & $\begin{array}{l}\text { CellSystems } \\
\text { Biotechnologie } \\
\text { GmbH }\end{array}$ & $\begin{array}{l}\text { OECD Test Guideline } 431 \\
\text { (meets performance standards } \\
2009 \text { ) }\end{array}$ & $\begin{array}{l}\text { Commission Regulation (EC) No 440/2008; } \\
\text { OECD Test Guideline } 431 \text { (June 2009) }\end{array}$ \\
\hline \multicolumn{4}{|c|}{ Skin Irritation Test } \\
\hline EpiSkin $^{\text {TM }}$ & SkinEthic & $\begin{array}{l}\text { OECD Test Guideline } 439 \\
\text { accepted in } 2010\end{array}$ & $\begin{array}{l}\text { Commission Regulation (EC) Nr 761/2009; } \\
\text { OECD Test Guideline } 439 \text { (April 2007) }\end{array}$ \\
\hline Epiderm $^{\mathrm{TM}}$ & MatTek & $\begin{array}{l}\text { OECD Test Guideline } 439 \\
\text { accepted in } 2010\end{array}$ & $\begin{array}{l}\text { Commission Regulation (EC) Nr 761/2009; } \\
\text { OECD Test Guideline } 439 \text { (April 2007; modified } \\
\text { Skin Irritation Test Method validated in } \\
\text { November 2008) }\end{array}$ \\
\hline $\begin{array}{l}\text { SkinEthic }{ }^{\mathrm{TM}} \\
\text { Rhe }\end{array}$ & SkinEthic & $\begin{array}{l}\text { OECD Test Guideline } 439 \\
\text { accepted in } 2010\end{array}$ & $\begin{array}{l}\text { Commission Regulation (EC) Nr 761/2009; } \\
\text { OECD Test Guideline } 439 \text { (November 2008) }\end{array}$ \\
\hline
\end{tabular}

NICEATM-ICCVAM: The National Toxicology Program Interagency Center for the Evaluation of Alternative Toxicological Methods (NICEATM) and the Interagency Coordinating Committee on the Validation of Alternative Methods (ICCVAM); ECVAM: European Center for the Validation of Alternative Methods; OECD: The Organisation for Economic Co-operation and Development.

\subsection{Development of Non-Commercial Human Skin Equivalents}

Several academic laboratories have developed their own HSEs models. The Stark Group from the German Cancer Research Center (Heidelberg, Germany) has developed a model for in vivo study of long-term skin reconstruction and epidermal function. The effect of fibroblasts and microenvironment on epidermal regeneration and tissue function was investigated [50]. The results indicated that: (a) the presence of fibroblasts, and the keratinocyte-fibroblast interactions play a critical role in epidermal tissue regeneration; (b) maintaining a correct microenvironment for epidermal tissue function is important. The HSEs model was also used to study the epidermal homeostasis and to provide experimental conditions for establishing a stem cell niche in vitro [60].

The Ponec, Bouwstra, and EI-Ghalbzouri groups in The Netherlands have developed the Leiden Human Epidermal (LHE) model, and have utilized it for the evaluation of skin corrosion of chemical compounds in accordance to European Center for the Validation of Alternative Methods (ECVAM) guidelines for testing the corrosive characteristics of chemical compounds [61]. They have developed a method to study HSEs under submerged aqueous conditions to mimic an in uteru environment [62]; 
and they also found that vitamin $\mathrm{C}$ has an essential role in the formation of stratum corneum barrier lipids [63]. In a recent study performed by EI-Ghalbzouri and Bouwstra groups, the barrier properties of two novel HSEs, the fibroblast-derived matrix model (FDM) and the Leiden epidermal model (LEM), were compared with the full-thickness collagen model (FTM) and human skin [64]. The results demonstrated that the barrier function of the FDM and LEM improved compared with that of the FTM, but all HSEs were more permeable than human skin.

The Morgan group (Boston, Massachusetts) has analyzed the effect of growth factors on cell proliferation for tissue engineering applications [65]. Their findings have indicated that keratinocyte growth factors (KGF) delayed differentiation and induced hyperproliferation. The KGF led to hyperthickening, crowding, and elongation of basal cells without disrupting the barrier function of the epidermis.

Recently, the Michniak group (the authors' own group) developed a full-thickness HSE model to serve as a permeation model for topical and transdermal formulations. The dermis of the model consists of human fibroblasts and bovine collagen; on top, keratinocytes are seeded and cultured at air-liquid interface, and differentiate into a highly differentiated epidermal layer. Michniak et al. reported that by adding clofibrate, ascorbic acid, and fatty acids into the growth media, lipid composition was improved with values obtained closer to that of human skin. The model overestimated (as all the other HSEs at present do $[64,66,67])$ the permeation of a number of compounds including caffeine, hydrocortisone, ketoprofen, DEET, malathion, and paraoxon by 2-7 fold when compared to human skin and matched the permeation profiles $(p<0.05)$ of EpidermFT ${ }^{\circledR}[68]$.

\section{Perspectives}

In summary, the skin as an organ has been reproduced using tissue engineering techniques; however, its barrier properties are still low resulting in an overestimation of compound permeability. Most models still lack appendages and a blood supply although melanocytes have been successfully added. The regeneration of hair follicles and sebaceous glands will be a challenge. There is evidence that introducing sebaceous glands into HSEs is a possibility [69]. Another interesting aspect is the regeneration of blood vessels and nerves. The use of stem cells for epidermal differentiation has been explored, but it is far from commercialization and clinical applications. Many more studies have to be performed to optimize the current skin models for both clinical use as well as compound permeability testing.

\section{Acknowledgements}

We thank our previous and current students Priya Batheja, Vishwas Rai, Alex Wei, and Yangmin Chen for their assistance in literature searches and laboratory work. We thank Dong-hua Yang at Fox Chase Cancer Center for the histology work.

\section{Conflict of Interest}

The authors declare no conflict of interest. 


\section{References}

1. Holbrook, K.A.; Wolff, K. The Structure and Development of Skin. In Dermatology in General Medicine, 6th ed.; Fitzpatrick, T.B., Eisen, A.Z., Wolff, K., Freedberg, I.M., Austen, K.F., Eds.; McGraw-Hill: New York, NY, USA, 1993.

2. Scheuplein, R.J.; Blank, I.H. Permeability of the skin. Physiol. Rev. 1971, 51, 702-747.

3. Briggaman, R.A.; Wheeler, C.E., Jr. The epidermal-dermal junction. J. Invest. Dermatol. 1975, $65,71-84$.

4. Parenteau, N.L.; Hardin-Young, J.; Ross, R.N. Skin. In Principles of Tissue Engineering, 2nd ed.; Lanza, R.P., Langer, R., Vacanti, J.P., Eds.; Academic Press: San Diego, CA, USA, 2000; pp. 879-890.

5. Hadgraft, J.; Guy, R.H. Feasibility Assessment in Topical and Transdermal Delivery: Mathematical Models and in Vitro Studies. In Transdermal Drug Delivery, 2nd ed.; Guy, R.H., Hadgraft, J., Eds.; Marcel Dekker, Inc.: New York, NY, USA, 2003; Chapter 1.

6. Zhang, Q.; Grice, J.E.; Li, P.; Jepps, O.G.; Wang, G.-J.; Roberts, M.S. Skin solubility determines maximum transepidermal flux for similar size molecules. Pharm. Res. 2009, 26, 1974-1985.

7. Vacanti, J.P.; Vacanti, C.A. The History and Scope of Tissue Engineering. In Principles of Tissue Engineering, 2nd ed.; Lanza, R.P., Langer, R., Vacanti, J.P., Eds.; Academic Press: San Diego, CA, USA, 2000; pp. 3-7.

8. Langer, R.; Vacanti, J.P. Tissue engineering. Science 1993, 260, 920-926.

9. Rheinwald, J.G.; Green, H. Serial cultivation of strains of human epidermal keratinocytes: The Formation of keratinizing colonies from single cells. Cell 1975, 6, 331-337.

10. Rheinwald, J.G.; Green, H. Epidermal growth factor and the multiplication of cultured human epidermal keratinocytes. Nature 1977, 264, 421-424.

11. Green, H.; Kehinde, O.; Thomas, J. Growth of cultured human epidermal cells into multiple epithelia suitable for grafting. Proc. Natl. Acad. Sci. USA 1979, 76, 5665-5668.

12. Bell, E.; Ehrlich, H.P.; Buttle, D.J.; Nakatsuji, T. Living tissue formed in vitro and accepted as skin-equivalent tissue of full thickness. Science 1981, 211, 1052-1054.

13. Deuel, T.F.; Kawahara, R.S.; Mustoe, T.A.; Pierce, A.F. Growth factors and wound healing: Platelet-derived growth factor as a model cytokine. Annu. Rev. Med. 1991, 42, 567-584.

14. Freed, L.E.; Hollander, A.P.; Martin, I.; Barry, J.R.; Langer, R.; Vunjak-Novakovic, G. Chondrogenesis in a cell-polymer-bioreactor system. Exp. Cell Res. 1998, 240, 58-65.

15. Freed, L.E.; Vunjak-Novakovic, G. Tissue Engineering Bioreactors. In Principles of Tissue Engineering, 2nd ed.; Lanza, R.P., Langer, R., Vacanti, J.P., Eds.; Academic Press: San Diego, CA, USA, 2000; Chapter 13, pp. 143-156.

16. Peppas, N.A.; Langer, R. New challenges in biomaterials. Science 1994, 263, 1715-1720.

17. Kohn, J.; Langer, R. Polymerization reactions involving the side chains of $\alpha$-l-amino acids. J. Am. Chem. Soc. 1987, 109, 817-820.

18. Pachence, J.M.; Kohn, J. Biodegradable Polymers. In Principles of Tissue Engineering, 2nd ed.; Lanza, R.P., Langer, R., Vacanti, J.P., Eds.; Academic Press: San Diego, CA, USA, 2000; pp. 263-277.

19. Lee, K.Y.; Mooney, D.J. Hydrogels for tissue engineering. Chem. Rev. 2001, 101, 1869-1879. 
20. Drury, J.L.; Mooney, D.J. Hydrogels for tissue engineering: Scaffold design variables and applications. Biomaterials 2003, 24, 4337-4351.

21. Peppas, N.A.; Carr, D.A. Impact of absorption and transport on intelligent therapeutics and nano-scale delivery of protein therapeutic agents. Chem. Eng. Sci. 2009, 64, 4553-4565.

22. Baptista, P.M.; Orlando, G.; Mirmalek-Sani, S.H.; Siddiqui, M.; Atala, A.; Soker, S. Whole Organ Decellularization- a Tool for Bioscaffold Fabrication and Organ Bioengineering. In Proceedings of the Annual International Conference of the IEEE Engineering in Medicine and Biology Society (EMBC '09), Minneapolis, MN, USA, 3-6 September 2009; pp. 6526-6529.

23. Atala, A.; Bauer, S.B.; Soker, S.; Yoo, J.J.; Retik, A.B. Tissue-engineered autologous bladders for patients needing cystoplasty. Lancet 2006, 367, 1241-1246.

24. Tissue Engineering and Cell Transplantation: US Markets for Skin Replacements and Substitutes; Report \#A426; Medtech Insight: Bridgeport, PA, USA, August 2010.

25. Guidance Document for the Conduct of Skin Absorption Studies. In OECD Environmental Health and Safety Publications, Series on Testing and Assessment, No. 28; Organisation for Economic Co-Operation and Development: Paris, France, 2004.

26. Panchagnula, R.; Stemmer, K.; Ritschel, W.A. Animal models for transdermal drug delivery. Methods Find. Exp. Clin. Pharmacol. 1997, 19, 335-341.

27. Kiowski, G.; Biedermann, T.; Widmer, D.S.; Civenni, G.; Burger, C.; Dummer, R.; Sommer, L.; Reichmann, E. Engineering melanoma progression in a humanized environment in vivo. J. Invest. Dermatol. 2011, 132, 144-153.

28. Commandeur, S.; Ho, S.H.; de Gruijl, F.R.; Willemze, R.; Tensen, C.P.; EI-Ghalbzouri, A. Functional characterization of cancer-associated fibroblasts of human cutaneous squamous cell carcinoma. Exp. Dermatol. 2011, 20, 737-742.

29. Tjabringa, G.; Bergers, M.; van Rens, D.; de Boer, R.; Lamme E.; Schalkwijk, J. Development and validation of human psoriatic skin equivalents. Am. J. Pathol. 2008, 173, 815-823.

30. MacNeil, S. Progress and opportunities for tissue-engineered skin. Nature 2007, 445, 874-880.

31. Groen, D.; Poole, D.S.; Gooris, G.S.; Bouwstra, J.A. Is an orthorhombic lateral packing and a proper lamellar organization important for the skin barrier function? Biochim. Biophys. Acta 2011, 1808, 1529-1537.

32. Nowak, J.A.; Fuchs, E. Isolation and culture of epithelial stem cells. Methods Mol. Biol. 2009, $482,215-232$.

33. Midwood, K.S.; Williams, L.V.; Schwarzbauer, J.E. Tissue repair and the dynamics of the extracellular matrix. Int. J. Biochem. Cell Biol. 2004, 36, 1031-1037.

34. Herndon, D.N.; Barrow, R.E.; Rutan, R.L.; Rutan, T.C.; Desai, M.H.; Abston, S. A comparison of conservative versus early excision. Therapies in severely burned patients. Ann. Surg. 1989, 209, 547-553.

35. Gallico, G.G.; O’Connor, N.E. Engineering a skin replacement. Tissue Eng. 1995, 1, 231-240.

36. Groeber, F.; Holeiter, M.; Hampel, M.; Hinderer, S.; Schenke-Layland, K. Skin tissue engineering- in vivo and in vitro applications. Adv. Drug Deliv. Rev. 2011, 63, 352-366.

37. O’Conner, N.E.; Mulliken, J.B.; Banks-Schlegel, S.; Kehinde, O.; Green, H. Grafting of burns with cultured epithelium prepared from autologous epidermal cells. Lancet 1981, 317, 75-78. 
38. Purdue, G.F. Dermagraft-TC pivotal efficacy and safety study. J. Burn Care Rehabil. 1997, 18, S13-S14.

39. Gentzkow, G.D.; Iwasaki, S.D.; Hershon, K.S.; Mengel, M.; Prendergast, J.J.; Ricotta, J.J.; Steed, D.P.; Lipkin, S. Use of dermagraft: A cultured human dermis to treat diabetic foot ulcers. Diabetes Care 1996, 19, 350-354.

40. Cuono, C.; Langdon, R.; McGuire, J. Use of cultured epidermal autografts and dermal allografts as skin replacement after burn injury. Lancet 1986, 327, 1123-1124.

41. Heimbach, D.; Luterman, A.; Burke, J.; Cram, A.; Herndon, D.; Hunt, J.; Jordan, M.; McManus, W.; Solem, L.; Warden, G.; Zawacki, B. Artificial dermis for major burns: A multi-center randomized clinical trial. Ann. Surg. 1988, 208, 313-320.

42. Shevchenko, R.V.; James, S.L.; James, S.E. A review of tissue-engineered skin bioconstructs available for skin reconstruction. J. R. Soc. Interface 2010, 7, 229-258.

43. Maruguchi, T.; Maruguchi, Y.; Suzuki, S.; Matsuda, K.; Toda, K.; Isshiki, N. A new skin equivalent: Keratinocytes proliferated and differentiated on collagen sponge containing fibroblasts. Plast. Reconstr. Surg. 1994, 93, 537-544.

44. Eaglstein, W.H.; Iriondo, M.; Laszlo, K. A composite skin substitute (graftskin) for surgical wounds: A clinical experience. Dermatol. Surg. 1995, 21, 839-843

45. Sabolinski, M.L.; Alvarez, O.; Auletta, M.; Mulder, G.; Parenteau, N.L. Cultured skin as a "smart material" for healing wounds: Experience in venous ulcers. Biomaterials 1996, 17, 311-320.

46. Bello, Y.M.; Falabella, A.F. The role of graftskin (apligraf) in difficult-to-heal venous leg ulcers. J. Wound Care 2002, 11, 182-183.

47. Boyce, S.T.; Kagen, R.J.; Greenhalgh, D.G.; Warner, P.; Yakuboff, K.P.; Palmieri, T.; Warden, G.D. Cultured skin substitutes reduce requirements for harvesting of skin autograft for closure of excised, full-thickness burns. J. Trauma 2006, 60, 821-829.

48. Ponec, M. Skin constructs for replacement of skin tissues for in vitro testing. Adv. Drug Deliv. Rev. 2002, 54, S19-S30.

49. Johsnon, E.W.; Meunier, S.F.; Roy, C.J.; Parenteau, N.L. Serial cultivation of normal human keratinocytes: A defined system for studying the regulation of growth and differentiation. In Vitro Cell. Dev. Biol. 1992, 28, 429-435.

50. Boehnke, K.; Mirancea, N.; Pavesio, A.; Fusenig, N.E.; Boukamp, P.; Stark, H.J. Effects of fibroblasts and microenvironment on epidermal regeneration and tissue function in long-term skin equivalents. Eur. J. Cell Biol. 2007, 86, 731-746.

51. Xie, Y.; Rizzi, S.C.; Dawson, R.; Lynam, E.; Richards, S.; Leavesley, D.I.; Upton, Z. Development of a three-dimensional human skin equivalent wound model for investigating novel wound healing therapies. Tissue Eng. Part C Method 2010, 16, 1111-1123.

52. Oliver, G.J.; Pemberton, M.A.; Rhodes, C. An in vitro model for identifying skin-corrosive chemicals. 1. Initial validation. Toxicol. in Vitro 1988, 2, 7-17.

53. Lelievre, D.; Justine, P.; Christiaens, F.; Bonaventure, N.; Coutet, J.; Marrot, L.; Cotovio, J. The Episkin Phototoxicity Assay (EPA): Development of an in vitro tiered strategy using 17 reference chemicals to predict phototoxic potency. Toxicol. in Vitro 2007, 21, 977-995. 
54. Gabbanini, S.; Lucchi, E.; Carli, M.; Berlini, E.; Minghetti, A.; Valgimigli, L. In vitro evaluation of the permeation through reconstructed human epidermis of essential oils from cosmetic formulations. J. Pharm. Biomed. Anal. 2009, 50, 370-376.

55. de Jager, M.; Groenink, W.; van der Spek, J.; Janmaat, C.; Gooris, G.; Ponec, M.; Bouwstra, J. Preparation and characterization of a stratum corneum substitute for in vitro precutaneuous penetration studies. Biochim. Biophys. Acta 2006, 1758, 636-644.

56. Wertz, P.W. Epidermal lipids. Semin. Dermatol. 1992, 11, 106-113.

57. Vicanova, J.; Boelsma, E.; Mommaas, A.M.; Kempenaar, J.A.; Forslind, B.; Pallon, J.; Egelrud, T.; Koerten, H.K.; Ponec, M. Normalization of epidermal calcium distribution profile in reconstructed human epidermis is related to improvement of terminal differentiation and stratum corneum barrier formation. J. Invest. Dermatol. 1998, 111, 97-106.

58. US and International Acceptance of Alternative Methods, 1998-2011 Chronological List, published by NICEATM-ICCVAM. Available online: http://iccvam.niehs.nih.gov/about/accept.htm (accessed on 23 December 2011).

59. The Regulatory Acceptance for Skin Corrosion and Skin Irritation can be found at the Method Validation website of ECVAM. Available online: http://ecvam.jrc.it/ (accessed on 23 December 2011).

60. Stark, H.J.; Boehnke, K.; Mirancea, N.; Willhauck, M.J.; Pavesio, A.; Fuesnig, N.E.; Boukamp, P. Epidermal homeostasis in long-term scaffold-enforced skin equivalents. J. Investig. Dermatol. Symp. Proc. 2006, 11, 93-105.

61. EI-Ghalbzouri, A.; Lamme, E.N.; van Blitterswijk, C.; Koopman, J.; Ponec, M. The use of PEGT/PBT as a dermal scaffold for skin tissue engineering. Biomaterials 2004, 25, 2987-2996.

62. Thakoersing, V.S.; Ponec, M.; Bouwstra, J.A. Generating of human skin equivalents under submerged conditions- mimicking the in utero environment. Tissue Eng. Part A 2010, 16, 1433-1441.

63. Ponec, M.; Weerheim, A.; Kempenaar, J.; Mulder, A.; Gooris, G.S.; Bouwstra, J.; Mommaas, A.M. The formation of competent barrier lipids in reconstructed human epidermis requires the presence of vitamin C. J. Invest. Dermatol. 1997, 109, 348-355.

64. Thakoersing, V.S.; Gooris, G.S.; Mulder, A.; Rietveld, M.; EI-Ghalbzouri, A.; Bouwstra, J.A. Unraveling barrier properties of three different in-house human skin equivalents. Tissue Eng. Part C 2012, 18, 1-11.

65. Andreadis, S.T.; Hamoen, K.E.; Yarmush, M.L.; Morgan, J.R. Keratinocyte growth factor induces hyperproliferation and delays differentiation in a skin equivalent model system. FASEB J. 2001, 15, 898-906.

66. Schmook, F.P.; Meingassner, J.G.; Billich, A. Comparison of human skin or epidermis models with human and animal skin in in-vitro percutaneous absorption. Int. J. Pharm. 2001, 215, 51-56.

67. Roy, S.D.; Fujiki, J.; Fleitman, J.S. Permeabilities of alkyl p-amino-benzoates through living skin equivalent and cadaver skin. J. Pharm. Sci. 1993, 82, 1266-1268.

68. Batheja, P.; Song, Y.; Wertz, P.; Michniak-Kohn, B. Effects of growth conditions on the barrier properties of a human skin equivalent. Pharm. Res. 2009, 26, 1689-1700. 
69. Wilkins, L.M.; Watson, S.R.; Prosky, S.J.; Meunier, S.F.; Parenteau, N.L. Development of a bilayered living skin construct for clinical applications. Biotechnol. Bioeng. 1994, 43, 747-756.

(C) 2012 by the authors; licensee MDPI, Basel, Switzerland. This article is an open access article distributed under the terms and conditions of the Creative Commons Attribution license (http://creativecommons.org/licenses/by/3.0/). 